\title{
Effects of online brand community on value creation practices: Mediating effects of community loyalty
}

\author{
Yongsoo Ha \\ College of Business \\ Kwangwoon University, South Korea
}

\section{Keywords}

Online brand community, social networking, impression management, community engagement, brand use, community loyalty

\begin{abstract}
Online brand community refers to a specialized, non-geographically bound, online community, based on social communications and relationships among brand's consumers. Consciousness of kind, rituals and traditions, and moral responsibility are the three markers of brand community. The present study tested the effects of online brand community by modeling the three community markers as formative indicators of online brand community. The effects of online brand community on four value creation practices, social networking, impression management, community engagement, and brand use, and the mediating effects of community loyalty were tested. Participants $(N=370)$ of this study were members of online brand communities. A survey-based empirical study was conducted using Amazon Mechanical Turk. Data were analyzed through structural equation modeling. Test results showed that,among the three brand community markers, consciousness of kind and rituals and traditions are formative indicators of online brand community while moral responsibility is not. The effects of online brand community on all four value creation practices were revealed.

Test results showed that online brand community has the strongest effects on social networking, moderate effects on community engagement and brand use, and the weakest effects on impression management practices. Community loyalty was found to fully mediate the relationship between online brand community and value creation practices. Implications for theory, practice, and future research are discussed.
\end{abstract}

Corresponding author: Yongsoo $\mathrm{Ha}$

Email addresses for corresponding author: hys@kw.ac.kr

First submission received: $8^{\text {th }}$ August 2017

Revised submission received: $1^{\text {st }}$ October 2017

Accepted: 27th November 2017

Acknowledgement: The present research has been conducted by the Research Grant of Kwangwoon University in $2017^{\prime \prime}$

\section{Introduction}

Online brand community or virtual brand community refers to a specialized, non-geographically bound, online community, based on social communications and relationships among brand's consumers (De Valck, Van Bruggen, \& Wierenga, 2009). Internet-use as its platform characterizes the broader concept of online brand community which includes entirely online and online/offline hybrid brand communities. There are several subsets of the broader concept of online brand community. It includes business-toconsumer virtual product support communities (Nambisan \& Baron, 2007), firm-hosted online communities (Wiertz \& de Ruyter, 2007), user-generated online communities, peer-to-peer problem solving communities (Mathwick, Wiertz, \& Ruyter, 2008), and social media based brand communities (Laroche, Habibi, Richard, \& Sankaranarayann, 2012).

Since maintaining one-on-one relationships with customers is not always feasible and efficient, brand communities were introduced as a way of serving customers (Laroche et al., 2012). Brand communities generate numerous activities within it including sharing information about the brand from various sources (Szmigin \& Reppel, 2001), perpetuating the history and rituals of the brand, and providing assistance to customers (Muniz \& O'Guinn, 2001). It establishes linkages with devoted users, 
who are a rich source of innovative ideas, rather than merely providing an additional communication channel (Anderson, 2005). Brand communities also provide social structure to customer-marketer relationships and significantly enhance customer loyalty (Muniz \& O'Guinn, 2001).

Brand community generates benefits not only for firms but also for its members. Customers join brand communities to identify themselves with focal brands so that their aspirational self-identity could be achieved (Laroche et al., 2012). Consumers search for symbols or signs in brand communities which could help them express whom they want to be and how they want to be identified by others (Elliott \& Wattanasuwan, 1998; Laroche et al., 2012). Participants derive asocial and hedonic value for themselves from participating in the brand community (Franke \& Piller, 2004) while enhancing brand loyalty (McAlexander, Schouten, \& Koenig, 2002).

Muniz and O'Guinn (2001) found evidence of brand communities in both face-to-face, offline environments and computer-mediated, online environments. While the initial concepts of the offline brand community had geographical and physical constraints, online brand communities transcend it due to the development of internet technology. Online brand communities have potential advantages for brands to find new ways to foster relationships with their customers (Kang, Lee, Lee \& Choi, 2007). The last decade has seen a proliferation of online brand communities as the adoption of advances in the internet, social media, and mobile technologies (Wirtz, Ambtman, Bloemer, Horvath, Ramaseshan, Klundert, Canli, \& Kandampully, 2013). Many brand communities emerged before the internet era added the online presence and functionality at later stages. Brand communities developed in today also start online first, before a real-world dimension emerges (Wirtz et al., 2013). As a consequence, by 2012, more than 50 percent of the top 100 global brands had established online brand communities which are operated on a global scale (Manchanda, Packard, \& Pattabhiramaiah, 2012).

Considering that online brand communities are becoming more important and prevalent in today's globally connected business world (Laroche et al., 2012), it is necessary for both marketers and researchers to have more insights about them. The theoretical construct of this study is based on previous brand community research. McAlexander et al. (2002) argued that the expectation of developing relationships with like-minded consumers motivate initial product acquisition for consumers who are looking for a sense of community. Muniz and O'Guinn (2001) found evidence of community markers (i.e., consciousness of kind, rituals and traditions, and moral responsibility) that exist in brand communities. Schau, Muniz, and Arnould (2009) categorized four types of value creation practices (i.e., social networking, impression management, brand use, and community engagement) generated in brand communities using a meta-analysis of nine brand communities.

This study aims to contribute to brand community studies in several ways; (a)testing the effects of online brand community as a whole by the linear sum of community markers, (b) testing the effects of online brand community on value creation practices, and (c) investigating the mediating effects of community loyalty in a relationship between online brand community and value creation practices.Toward this goal, first, we modeled a nomological network of relationships between community markers, online brand community, value creation practices, and community loyalty. Then, we tested the network quantitatively using a structural equation model with a survey data from members of various types of online brand communities.

\section{Literature Review and Hypotheses Development 1. Features of Online Brand Community}

Traditional brand communities have been oriented strongly toward the brand itself. There have been a broad agreement in the brand community literatures that product categories which have expressive, hedonic, and experiential qualities are more likely to build a successful brand community than others (McAlexander\& Schouten, 1998). However, Wirtz et al. (2013) identified that the core focus of online brand communities could be not only the brand itself but also the wider shared interests among its members. Thus, brands with weak brand identity also could build a successful online brand community if they focus more on the social links rather than the brand itself (Fournier \& Lee, 2009).

Members of online brand community find proximity, affiliation, social interaction and bonding with each other (Hoffman \& Novak, 1996). In online brand community, contents are created by members while community members participate in interactive communications and reciprocal activities to earn 
specific rewards for themselves (Nambisan \& Baron, 2007). Consumers interact with each other using virtual interaction and communication tools such as registry, guest book, bulletin boards, electronic discussion forums, chat rooms, newsgroups, and/or blogs (De Valck et al., 2009; Muniz \& O'Guinn, 2001). These tools enable new and extended forms of interactive consumer experiences, and facilitate an aggregation of collective expertise on individual topics. As online brand community accumulates past contents inexpensively, it creates a capital of knowledge and increases its value for all members (Brodie, Ilic, Juric, \& Hollebeek, 2013). Moreover, once it is established, online brand community facilitates longterm, intimate contacts without the loss of the social links which frequently occurs in the offline environments (Ba, 2001).

The information provided by a brand community is more reliable source for consumers than information provided by marketers (McAlexander et al., 2002). Information sharing is prevalent in online brand community due to the capabilities of internet technology (McAlexander et al., 2002). Online platform facilitates information dissemination, helps consumers to solve problems and have a positive consumption experience, and demonstrates commitment to a collective (Muniz \& O'Guinn, 2001). Online brand communities exert significant influence on consumers since the communities formed for the purpose of sharing information, rather than for commercial reasons, have greater impacts on members' opinions and purchase intentions (Algesheimer, Dholakia, \& Herrmann, 2005).

\section{Markers of Brand Community}

Based upon sociology literature, Muniz and O'Guinn (2001) identified three core markers of a brand community; consciousness of kind, rituals and traditions, and moral responsibility. Muniz and O'Guinn (2001) also found evidence that supports the existence of community markers in computermediated environments. Muniz and O'Guinn (2001) found that members of community share "we-ness" and feel that "they sort of know each other", even if they have never met. Consciousness of kind is the most important element of community which is the shared intrinsic connection felt among community members (Gusfield, 1978), or a shared knowing of belonging (Weber, 1978). In brand communities, members feel connections not only to the brand but also toward other members. Members show a critical demarcation between users of their brand and users of other brands which makes them different or special in comparison to non-members (Muniz \& O'Guinn, 2001).

Rituals and traditions are social processes that enable reproduction and transmission of meanings of the community (Muniz \& O'Guinn, 2001). It is a symbolic form of communication repeated over time in a systematic fashion. Rituals stabilize brand community's identity by delineating boundaries, specifying expected roles, and defining rules (Wolin \& Bennett, 1984). Knowing these rituals and traditions acts as a form of cultural capital within the brand community (Bourdieu, 1984). Moral responsibility is a sense of duty to the communityand individual members (Muniz \& O'Guinn, 2001). Although brand communities are intentional, voluntary, and characterized by partial and personal involvement (Jannowitz, 1952), a social, moral consciousness exists among community members. Brand community members recognize "what is right and wrong" and "appropriate and inappropriate". Since moral responsibility goes only so far in the brand community, it reveals the boundary of the community. It produces collective action and contributes to the cohesion of the community (Muniz \& O'Guinn, 2001).

With respect to the markers of the brand community, previous research found online brand communities to be very consistent with traditional, offline brand communities (Brodie et al., 2013; Laroche et al., 2012; Wirtz et al., 2013). Online brand community shows community-like qualities as understood in sociology, and address identity, meaning, and status related concerns for its members (Schau et al., 2009).

\section{Brand Community Markers and Online Brand Community}

In brand community studies, the effects of brand community as a whole have not been fully investigated. Previous research on brand communities tested the effects of brand community by using variables such as members' participation in the community (Thompson \& Sinha, 2008), community integration (McAlexander et al., 2002), community/company identification (Marzocchi, Morandin, \& Bergami, 2013), or community commitment (Hur, Ahn, \& Kim, 2011).However, since these variables are components of brand community rather than the brand community itself, it only could partially explain the influence of brand community. 
The present study aims to test the influence of online brand community as a whole by the linear sum of brand community markers. Ethnographic evidences support that strong and effective communities are built upon community communalities (Laroche et al., 2012).Muniz and O'Guinn (2001) found three community markers in both face-to-face and computer-mediated environments. Laroche et al. (2012) stated that healthy brand communities have a presence in all community markers and a depth within each marker that strengthen the community. Considering the theoretical backgrounds regarding brand community markers and brand community, the influence of online brand community as a whole could be tested based on its community commonalities. In this regard, this study models community markers as formative indicators that constitute online brand community, and postulates a causal relationship between brand community markers and the levels of online brand community.

Thus, the first hypothesis of the study is that

H1: As consciousness of kind, rituals and traditions, and moral responsibility strengthen in online brand community, the levels of online brand community will increase.

In this study, the online brand community construct is modeled as a formative indicator construct (Jarvis, Mackenzie, \& Podsakoff, 2003). A formative indicator construct can be estimated only when it is placed within a nomological relationship that incorporates results of the latent variable (Bollen, 1989; Mathwick et al., 2008). Therefore, this study simultaneously modeled value creation practices as consequences of the latent construct to measure the levels of the online brand community.

In testing such relationship, the present study aims to measure online brand community markers in a quantitative way. Previous research on brand communities have been largely conducted in a qualitative way using idiographic analysis (Fournier, 1998), ethnographic analysis (McAlexander et al., 2002), netnographic analysis (Muniz \& O'Guinn, 2001), naturalistic observation of community activities (Schau et al., 2009), observation of communication in online forums (Thompson \& Sinha, 2008), or indepth interviews with online brand community members (Bryman \& Bell, 2007; Kozinets, 2002).Brand community researchers frequently assumed the presence of brand community markers based on observations or analyzation of transcripts or communications rather than to measure it using established scales. Measuring brand community markers in a quantitative way may help to ensure the presence of community commonalities in a brand community study.

\section{Value Creation Practices of Online Brand Community}

Online brand community generates value creation practices within it (Larocheet al., 2012). Consumers create value through participating in brand community and engaging in practices (Schau et al., 2009). Using a meta-analytic approach, Schau et al. (2009) induced twelve value creating practices across nine brand communities and organized it into four thematic categories; social networking, impression management, community engagement, and brand use.

Social networking practices function as creating, enhancing, and sustaining ties among brand community members. These practices emphasize on the homogeneity of the brand community, or the similarities across its members and their normative behavioral expectations of themselves. Social networking practices create value by providing affective resources within a sympathetic social network and reinforce the social or moral bonds within the community (Schau et al., 2009).Impression management practices function as creating favorable impressions of the brand, brand enthusiasts, and the brand community. It has an external, outward focus in the social universe beyond the brand community. While members conducting impression management practices, they act as altruistic emissaries and ambassadors of good will. It creates value by expanding the community and its member base while enhancing the brand perception outside the brand community (Schau et al., 2009).Community engagement practices function as reinforcing members' escalating engagement with the brand community. Community engagement practices are competitive and provide members with social capital within the community. These practices focus on community heterogeneity or the distinctions among members and subsets of members. It creates value by building brand meanings associated with the use journey (Schau et al., 2009). Brand use practices function as improving or enhancing the use of the focal brand. Brand use practices create value by preserving the brand's appearance and offering reproducible solutions to user challenges (Schau et al., 2009). 
Previous research showed that healthy, prolonged communities generate all value creation practices within it (Schau et al., 2009), and online brand communities have the same advantages and benefits as traditional, offline brand communities (Laroche et al., 2012; Muniz \& O'Guinn, 2001). However, due to its distinctive features, the extent and effects of online brand community on value creation practices could be different from those of traditional, offline brand communities. Considering the values that online brand community practices create for both consumers and marketers (e.g., building brand loyalty, enhancing brand experience, and institutionalizing consumption behaviors), it is important to make online brand community members engaging in value creation practices (Laroche et al., 2012; Schau et al., 2009).

The present study hypothesizes that online brand community manifested by three community markers will generate diverse value creation practices. As the levels of online brand community increase, it may foster members to participate and/or engage in community activities more deeply and generate diverse value creation practices.

Thus, the second hypothesis of the study is that

H2: As the levels of online brand community increase, it will lead members to be more engaged in value creation practices.

H2a: As the levels of online brand community increase, it will lead members to be more engaged in social networking practices.

H2b: As the levels of online brand community increase, it will lead members to be more engaged in impression management practices.

H2c: As the levels of online brand community increase, it will lead members to be more engaged in community engagement practices.

H2d: As the levels of online brand community increase, it will lead members to be more engaged in brand use practices.

\section{Community Loyalty}

Despite there have been many research conducted on brand community and online brand community, the role of community loyalty, a loyalty toward the brand community, has not been studied thoroughly. Although a particular definition of community loyalty has not been identified in brand community research yet, there exist the two of closely related concepts that could be used to understand the meaning of community loyalty.

Group loyalty is one specific domain that is related to community loyalty. Group loyalty refers to an adherence to a social unit to which one belongs, as well as its goals, symbols, and benefits (James \& Cropanzano, 1994). Scott (1965) defined group loyalty more specifically as "being a devoted member of the group, never criticizing it to outsiders, and working hard to get it ahead of other groups". Brewer and Brown (1998) defined that "group loyalty is represented in adherence to in-group norms and trustworthiness in dealings with fellow in-group members". Van Vugt and Hart (2004) defined group loyalty as "the desire to forgo attractive alternatives for group membership". They stated that group loyalty is one important psychological and behavioral force that contributes to group stability and integrity. Levine and Moreland (2002) stated that group loyalty is a multifaceted construct comprised of affective, cognitive, and behavioral factors.

The concept of organizational loyalty also relates to community loyalty. Organizational loyalty refers to "a bond formed either to an organization or to some person or group within it that can be either individually or collectively forged" (Adler \& Adler, 1988).Adler and Adler (1988) stated that organizational loyalty consists of affective, cognitive, and behavioral elements. It consists of feelings of belongingness, attachment, and wanting to be part of something; it incorporates trust and the voluntary alignment of self with the group; it involves willingness to contribute part of oneself and follow the leadership or guidelines of the organization (Adler \& Adler, 1998).

Considering that both group loyalty and organizational loyalty are multifaceted construct comprised of cognitive, affective, and behavioral elements (Adler \& Adler, 1998; Levine \& Moreland, 2002), the present study defined community loyalty as; members voluntarily align themselves with the community, have a feeling of belonging and a belief that members matters to one another, and engage in innovative and spontaneous activities that go beyond their role prescriptions. Although both group 
loyalty and organizational loyalty are multifaceted constructs, previous research often measured their behavioral dimension only (Van Vugt \& Hart, 2004; Zdaniuk\& Levine, 2001). The present study aims to measure community loyalty including all three dimensions of community loyalty by modeling it as it consists of group identification (Bagozzi \& Dholakia, 2006; Hinkle, Taylor, Fox-Cardamone, \& Crook, 1989) and organizational citizenship behavior (Podsakoff, Mackenzie, Moorman, \& Fetter, 1990).

Group identification influences affective, perceptual, and behavioral reactions to group membership. Individuals with high group identification view their group and group members as more positive (Brewer \& Brown, 1998; Ellemers, Spears, \& Doosje, 2002), perceive similarity to and liking for other members (Brewer \& Brown, 1998; Wilder, 1986), perceive themselves as representatives of the group (Van Vugt \& Hart, 2004), and choose to work for the groupmore often than individuals with low identification (Barreto \& Ellemers, 2000). Group loyalty is largely depend on the strength and nature of group members' identification with the group (Van Vugt \& Hart, 2004). Group identification leads members to a collectivist motivation, a desire to enhance the welfare of the group as a whole (Batson, Batson, Todd, Brummett, Shaw, \& Aldeguer, 1995). Group identification makes salient a norm of social responsibility for in-group members, which enhances cooperation and helping among members (Dovidio, 1984; Stern, 1995). Group identification also makes members conforming to group's non-abandonment norm and placing group's interests above their own (Hertel \& Kerr, 2001; Zdaniuk \& Levine, 2001).

Organizational citizenship behaviors represent the behavioral dimension of community loyalty. It refers to discretional behaviors that are not part of members' formal role requirements, but nevertheless promote the effective functioning of the organization (Organ, 1988). Every organization depends significantly on acts of altruism, gesture of goodwill, cooperation, helpfulness, suggestions, and other instances of citizenship behavior (Katz, 1964). It lubricates the social machinery of the organization, provides flexibility needed to work through many unforeseen contingencies, and allows participants to depend on each other (Smith et al., 1983).

The present study postulates the influence of online brand community on community loyalty and the mediating effects of community loyalty in a relationship between online brand community and value creation practices. Since, individuals can identify themselves with multiple targets (Johnson, Morgeson, Ilgen, Meyer, \& Lloyd, 2006), brand community members identify themselves with both the brand and the community (Ahearne et al., 2005; Algesheimer et al., 2005; Marzocchi et al., 2013; Shen \& Chiou, 2009). Brodie et al. (2013) revealed that online brand community members engage both with the themes, including brands, products and services, and with the community, their community roles and other community members. Consumers often initially engage with the brand, and then progress to interactions with other members of the community (Brodie et al., 2013). Marzocchi et al. (2013) revealed that brand identification affects cognitive process while community identification affects emotional and affective dimensions of brand schema.

Schau et al. (2009) stated that as social relationships among members sustained over several years, social values associated with brand communities expand beyond brand boundaries. For brand community members, brand use is often secondary to community engagement. For example, in community engagement practices such as staking, members delineate their specific domain of participation or engagement even within the brand community. Moreover, due to the social identity they had achieved within the community, longtime members frequently remain in the brand community even after they stop using the focal brand. In both cases, members are more engaged in the community, where they belong to, rather than the brand itself (Schau et al., 2009).Strong and effective online brand community systemically reinforces consciousness of kind among members, reproduces rituals and traditions of the community, and its members spontaneously carry out moral responsibility (McAlexander et al., 2002; Muniz \& O'Guinn, 2001). Thus, strong online brand community members may show high levels of community identification, conform to organizational citizenship behavior, and as a consequence, they may show a heightened community loyalty. Therefore, the third hypothesis of this study is that; H3: As the levels of online brand community increase, it will enhance members' community loyalty.

Considering that online brand community members often opportunistically engage in relationships since the costs for participating and leaving the community is low in computer-mediated environments (Wirtz et al., 2013), it is more important to understand the role of community loyalty in an 
online setting. When members have community loyalty, they identify themselves with the community, form a collectivist motivation, and involve in spontaneous activities (Batson et al., 1995; Katz, 1964). Thus, online brand community members may engage more deeply in value creation practices when they participate with community loyalty. Therefore, the fourth hypotheses of this study are that;

H4: Community loyalty will mediate the relationship between online brand community and value creation practices.

H4a: Community loyalty will mediate the relationship between online brand community and social networking practices.

H4b: Community loyalty will mediate the relationship between online brand community and impression management practices.

H4c: Community loyalty will mediate the relationship between online brand community and brand use practices.

H4d: Community loyalty will mediate the relationship between online brand community and community engagement practices.

\section{Methodology \\ 1. Participants}

Participants of this study were $(\mathrm{N}=370)$ members online brand communities. Considering that the aim of this study is investigating the effects of online brand community in general, participants should not be limited by both types and product categories of online brand community.

This study collected data from members of five types of online brand community; business-toconsumer virtual product support community, firm-hosted online community, user-generated online community, peer-to-peer problem-solving community, and social media based brand community. Brand community studies have frequently been conducted with product categories that are more likely to trigger brand identification processes (Algesheimer et al., 2005; Marzocchi et al., 2013; McAlexander et al., 2002). However, although product categories which have expressive, hedonic, and experiential qualities are believed to build brand community more easily, mundane products with weak brand identity also can build strong online brand community (Thompson \& Sinha, 2008; Wirtz et al., 2013). Thus, members of any kinds of online brand community are eligible for being the subject of this study.

\section{Survey Procedure}

Data were collected online using Amazon Mechanical Turk in July 2015. Previous brand community research largely conducted under high-context interaction situations such as brandfest (Marzocchi et al., 2013; McAlexander et al., 2002). However, such high-context interaction situations may cause situational bias since participants are induced to concentrate on brand community markers in a limited time and space (Marzocchi et al., 2013). This study collected data through Amazon Mechanical Turk. Amazon Mechanical Turk is a reliable source of experimental data in decision-making and judgment (Paolacci, Chandler, \& Ipeirotis, 2010). The quality of data obtained by Amazon Mechanical Turk met or exceed the psychometric standards associated with published research (Buhrmester, Kwang, \& Gosling, 2011).

All measurement scales used in this study were derived from established studies (Table 1). The survey was introduced as an opinion survey of "consumer behavior in online brand community". Definition, scope, types, and examples of online brand community were provided at the beginningof the survey to help participants to understand the meanings of online brand community. Two screening questions were presented at the first stage of the survey. Participants were asked to check their eligibility for participating in the study by browsing provided links of online brand communities' websites. The provided links representeach type of online brand community; business-to-consumer virtual product support community (e.g. Apple Support Community), firm-hosted online community (e.g. Harley Davidson Owners Group), user-generated online community (e.g. International Lego users group), peerto-peer problem solving community (e.g. Mac User's Forum), and social media based brand community (e.g. Apple Mac User for Beginner on Facebook). Once they were qualified for participating in the study, they were asked to write the name of online brand community they associate themselves with. 


\begin{tabular}{|c|c|c|c|}
\hline Construct & Items & $\begin{array}{l}\text { Factor } \\
\text { Loadings }\end{array}$ & C.R \\
\hline \multirow{2}{*}{$\begin{array}{l}\text { Consciousness of } \\
\text { Kind } \\
\text { (Laroche et al., } \\
\text { 2012) }\end{array}$} & An intrinsic connection is felt among the members & .914 & 11.23 \\
\hline & $\begin{array}{l}\text { A general sense of difference exists from members who are } \\
\text { NOT in your online brand community }\end{array}$ & .651 & 9.71 \\
\hline \multirow{2}{*}{$\begin{array}{l}\text { Rituals and } \\
\text { Traditions } \\
\text { (Laroche et al., } \\
\text { 2012) }\end{array}$} & $\begin{array}{l}\text { I think these traditions contribute towards a specific culture of } \\
\text { the online brand community }\end{array}$ & .781 & 9.87 \\
\hline & $\begin{array}{l}\text { I recollect vital social traditions or rituals specific to the online } \\
\text { brand community }\end{array}$ & .813 & 10.27 \\
\hline \multirow{2}{*}{$\begin{array}{l}\text { Moral } \\
\text { Responsibility } \\
\text { (Laroche et al., } \\
\text { 2012) }\end{array}$} & $\begin{array}{l}\text { The online brand community engages in integrating and } \\
\text { retaining members }\end{array}$ & .979 & 21.79 \\
\hline & $\begin{array}{l}\text { The members of the online brand community assist/advise } \\
\text { other members of the same community in the proper use of the } \\
\text { brand }\end{array}$ & 691 & 18.32 \\
\hline \multirow{2}{*}{$\begin{array}{l}\text { Social } \\
\text { Networking } \\
\text { (Hsieh et al., } \\
\text { 2005) }\end{array}$} & I share my opinions on the online brand community & .682 & 10.72 \\
\hline & The online brand community is concerned with my needs & 679 & 10.70 \\
\hline \multirow{2}{*}{$\begin{array}{l}\text { Impression } \\
\text { Management } \\
\text { (Laroche et al., } \\
\text { 2012) }\end{array}$} & $\begin{array}{l}\text { The online brand community encourages discussions related } \\
\text { to company, brand, or the product }\end{array}$ & .889 & 6.32 \\
\hline & $\begin{array}{l}\text { Members actively engage in discussions in order to justify } \\
\text { their reasons for their affinity towards the brand }\end{array}$ & .636 & 3.92 \\
\hline \multirow{2}{*}{$\begin{array}{l}\text { Community } \\
\text { Engagement } \\
\text { (Algesheimer et } \\
\text { al., 2005) }\end{array}$} & I benefit from following the online brand community's rules & 633 & 7.64 \\
\hline & $\begin{array}{l}\text { I am motivated to participate in the online brand community's } \\
\text { activities because Iam able to support other members }\end{array}$ & .712 & 10.84 \\
\hline \multirow[t]{2}{*}{$\begin{array}{l}\text { Brand Use } \\
\text { (Laroche et al., } \\
\text { 2012) }\end{array}$} & $\begin{array}{l}\text { Members of my community share experiences about their } \\
\text { successful and unsuccessful attempts at customization of the } \\
\text { product }\end{array}$ & .839 & 12.10 \\
\hline & $\begin{array}{l}\text { Members of my community share useful tips about better use } \\
\text { of the product or brand }\end{array}$ & .727 & 10.77 \\
\hline \multirow{2}{*}{$\begin{array}{l}\text { Community } \\
\text { Loyalty }\end{array}$} & Community Identification & .867 & 11.73 \\
\hline & Organizational Citizenship Behavior & .763 & 10.68 \\
\hline \multirow{4}{*}{$\begin{array}{l}\text { Community } \\
\text { Identification } \\
\text { (Bagozzi\& } \\
\text { Dholakia, 2006; } \\
\text { Hinkle et al., } \\
\text { 1989) }\end{array}$} & $\begin{array}{l}\text { I have strong feelings of belongingness toward the online } \\
\text { brand community }\end{array}$ & .761 & 14.48 \\
\hline & I identify myself as a member of the online brand community & .737 & 11.02 \\
\hline & I am attached to the online brand community & .753 & 14.33 \\
\hline & $\begin{array}{l}\text { I feel strong ties with other members of the online brand } \\
\text { community }\end{array}$ & .824 & 15.28 \\
\hline \multirow{3}{*}{$\begin{array}{l}\text { Organizational } \\
\text { Citizenship } \\
\text { Behavior } \\
\text { (Podsakoff et al., } \\
\text { 1990) }\end{array}$} & $\begin{array}{l}\text { I willingly help other members who have brand-related } \\
\text { problems }\end{array}$ & .788 & 13.86 \\
\hline & I try to help other members who are in need & .727 & 13.12 \\
\hline & $\begin{array}{l}\text { I try to help orient new members even though it is not } \\
\text { required }\end{array}$ & .746 & 13.42 \\
\hline
\end{tabular}

Table 1.Measurement Model and Results

\section{Results}

\section{Analysis Plan}

This study specified online brand community construct as a multidimensional formative indicator construct (Figure 1). The misspecification of the direction of causality between a construct and its measures can cause inaccurate results about the structural relationships between constructs (Law \& Wong, 1999). Even though a reflective indicator construct is conceptually appropriate in many instances, 
for some constructs, a direction of causality should be viewed as flowing from the measures to the construct, rather than vice versa (Bagozzi, 1981; Blalock, 1964; Fornell \& Bookstein, 1982).

The present study specified online brand community construct as reflective first-order, formative second-order model. Jarvis, Mackenzie, and Podsakoff (2003) stated that whether a construct is modeled as unidimensional or multidimensional may depend on the level of abstraction used to define the construct. It is also possible for a model to have both formative and reflective indicators. A construct should be viewed as a formative model when; (a) the direction of causality between measures and constructs flows from the indicators to the latent construct, (b) the indicators jointly determine the conceptual meaning of the construct as a group, (c) the indicators are viewed as defining characteristics of the latent construct, and (d) the indicators are not interchangeable with each other (Jarvis et al., 2003).

Consciousness of kind, rituals and traditions, and moral responsibility are independent markers of online brand community (Muniz \& $\mathrm{O}^{\prime}$ Guinn, 2001). Considering that each community marker is unique and essential element that jointly determines brand community (Muniz \&O'Guinn, 2001), the direction of causality between indicators and a latent construct should be viewed as flowing from the markers to online brand community (Anderson \&Gerbing, 1988). Thus, the proposed model measured the three brand community markers using reflective measures, and then, these three first-order dimensions were modeled as being related to online brand community construct as formative indicators. Four value creation practices constructs, social networking, impression management, community engagement, and brand use constructs, were modeled as reflective indicator model. Community loyalty construct was modeled as multidimensional reflective construct. Community identification and organizational citizenship behavior were first measured using reflective measures, and they were subsequently modeled as the two reflective indicators of community loyalty.

The data was analyzed through structural equations modeling using AMOS 20. The goodness-offit of both the measurement model and structural model were assessed with the chi-square test (CMIN), the goodness-of-fit index (GFI), the comparative fit index (CFI), and the root mean square error of approximation (RMSEA). The research model is presented in Fiure1.

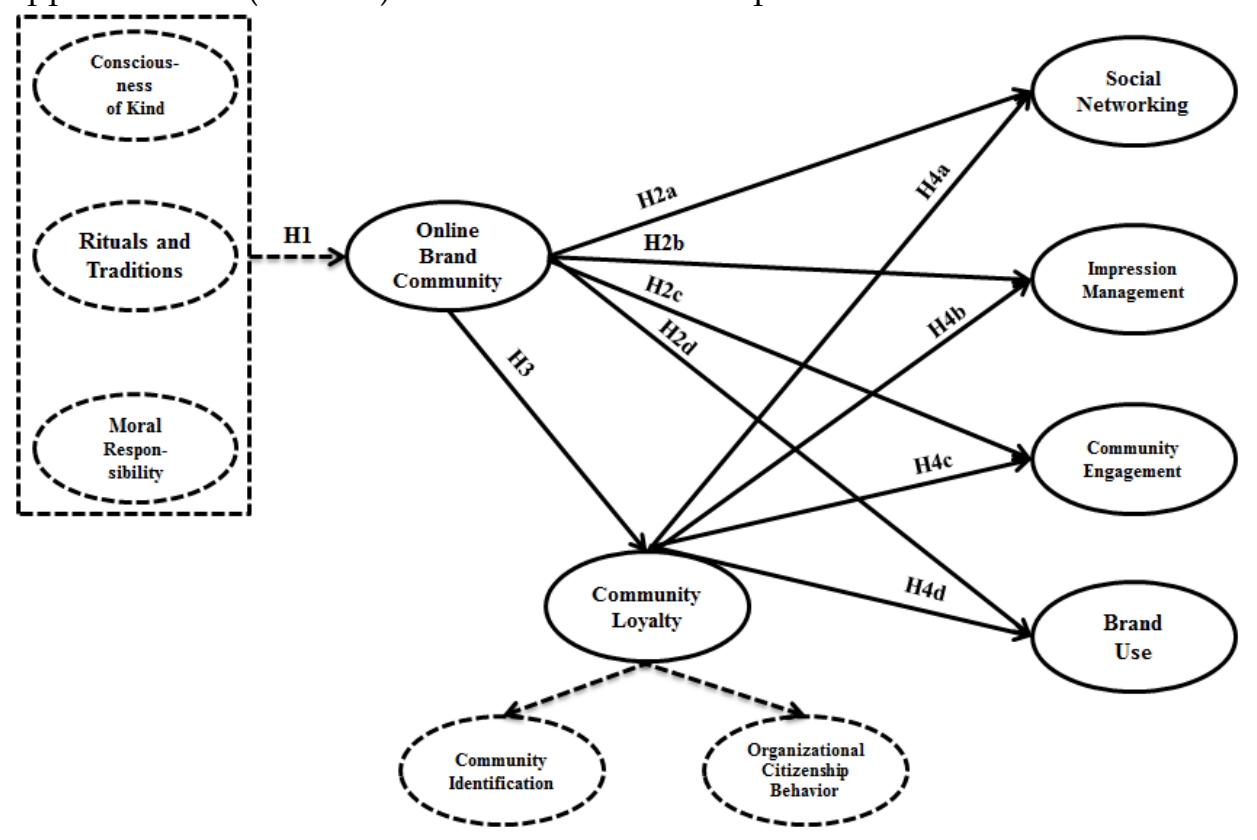

Figure 1.Research Model

\section{Measurement Model}

Confirmatory factor analysis was conducted with the full data. The measurement model was estimated by investigating reliabilities of individual items, a convergent validity of the measures associated with each construct, and a discriminant validity between constructs (Fornell \& Cha, 1994; White, Varadarajan, \& Dacin, 2003). 
Each measure's loading on its respective construct was examined to test item reliability. All measures with loadings greater than .50 were retained for analysis (Hulland, 1999). All 21 retained itemsin the model showed loadings greater than .63. All items and their associated factor loadings are shown in Table 1.

Internal consistency and convergent validity of the constructs were confirmed by Cronbach's alpha with a minimum of .70 (Cronbach\& Furby, 1970; Nunnally, 1978), the average variance extracted (AVE) with a minimum of .50 (Fornell \& Larcker, 1981; Bagozzi \& Yi, 1988), and the construct reliability with a minimum of .70 (Fornell \& Larcker, 1981). All constructs in the measurement model except for the community engagement construct showed Cronbach's alpha value greater than .70 and AVEs greater than .50. Community engagement construct showed Cronbach's alpha of .681, and AVE of .476, which fell marginally below the recommendation cutoff, but tolerable to be included in the model. Construct reliabilities of all constructs were greater than .70. Cronbach's alpha, the average variance extracted (AVE), and the construct reliability for all constructs are shown in Table 2.

\begin{tabular}{|l|l|l|l|}
\hline Construct & $\begin{array}{l}\text { Cronbach's } \\
\text { Alpha }\end{array}$ & AVE & $\begin{array}{l}\text { Construct } \\
\text { Reliability }\end{array}$ \\
\hline Consciousness of Kind & .743 & .713 & .829 \\
\hline Rituals and Traditions & .771 & .508 & .673 \\
\hline Moral Responsibility & .822 & .862 & .924 \\
\hline Social Networking & .734 & .526 & .732 \\
\hline Impression Management & .722 & .744 & .849 \\
\hline Community Engagement & .681 & .476 & .70 \\
\hline Brand Use & .757 & .70 & .821 \\
\hline Community Loyalty & .830 & .730 & .843 \\
\hline Community Identification & .811 & .504 & .803 \\
\hline Organizational Citizenship Behavior & .797 & .568 & .80 \\
\hline
\end{tabular}

Table 2.Internal Consistency and Convergent Validity

As the online brand community construct is modeled as a second-order formative indicators model, the measurement model does not predict that three community markers will be correlated (Jarvis et al., 2003). In such case, traditional notions of internal consistency reliability are not appropriate to apply to the set of sub-dimensions of a second-order construct (Bollen\& Lennox, 1991; Edwards, 2003). Thus, internal consistency reliabilities of the online brand community construct were not assessed.

Discriminant validity was achieved for all constructs. The square root of the average variance extracted for all constructs exceeded the correlation between two latent constructs (Fornell \& Larcker, 1981).The final measurement model exhibited satisfactory goodness-of-fit statistics (Bagozzi \& Yi, 1988); $\mathrm{X}^{2}(177)=328, \mathrm{X}^{2} / \mathrm{df}=1.85, \mathrm{p}=.000, \mathrm{GFI}=.924, \mathrm{CFI}=.953, \mathrm{RMSEA}=.048$. The structural model showed satisfactory goodness-of-fit statistics (Bagozzi \& Yi, 1988); $\mathrm{X}^{2}(195)=399, \mathrm{X}^{2} / \mathrm{df}=2.04, \mathrm{p}=.000, \mathrm{GFI}=.909$, $\mathrm{CFI}=.936$, RMSEA $=.053$. The chi-square was significant because of the large sample size $(\mathrm{N}=370)$, but the $\mathrm{X}^{2} / \mathrm{df}$ was less than 3 which indicated a satisfactory model fit. All other fit statistics were within acceptable ranges for both the measurement and the structural models.

\section{Online Brand Community Markers and Consequences}

The effects of community markers on online brand community, hypothesis 1 , were tested. Given that online brand community is modeled as a second-order formative latent construct, it was specified as the linear sum of consciousness of kind, rituals and traditions, and moral responsibility. A formative indicator model can be estimated only when it is modeled within a nomological net that incorporates consequences of the latent variable (Bollen, 1989). Therefore, hypothesis 2 and hypothesis 3, which relate to the effects of online brand community on value creation practices and community loyalty, were simultaneously modeled (Jarvis et al., 2003).

Hypothesis 1 was partially supported (Table 3 ). The results indicate that consciousness of kind ( $\beta$ $=.92, \mathrm{p}<.001)$ and rituals and traditions $(\beta=.39, \mathrm{p}<.001)$ are significant formative dimensions of an online 
brand community. However, moral responsibility showed non-significant impact on the latent construct, and the relationship was negative $(\beta=-.06, \mathrm{p}=.32)$.

Hypotheses $2 \mathrm{a}$ through $2 \mathrm{~d}$ were supported (Table 3 ). The test of hypotheses 2 showed positive relationships between online brand community and four value creation practices; social networking ( $\beta$ $=.95)$, impression management $(\beta=.22)$, community engagement $(\beta=.84)$, and brand use $(\beta=.64)$. Hypotheses 2 were supported with significance levels of $\mathrm{p}<.001$ except for the impression management construct $(\mathrm{p}<.01)$.

\begin{tabular}{|c|c|c|c|}
\hline & Path & $\begin{array}{l}\text { Path } \\
\text { Coefficient }\end{array}$ & C.R \\
\hline \multirow[t]{3}{*}{$\mathrm{H} 1$} & $\begin{array}{l}\text { Consciousness of Kind } \\
\text { Online Brand Community }\end{array}$ & .92 & ${ }^{* *} 12.47$ \\
\hline & $\begin{array}{l}\text { Rituals and Traditions } \\
\text { Online Brand Community }\end{array}$ & .39 & $* * 5.61$ \\
\hline & $\begin{array}{l}\text { Moral Responsibility } \\
\text { Online Brand Community }\end{array}$ & .32 & -.996 \\
\hline \multirow[t]{4}{*}{$\mathrm{H} 2$} & $\begin{array}{l}\text { Online Brand Community } \\
\text { Social Networking }\end{array}$ & .95 & $* * 8.11$ \\
\hline & $\begin{array}{l}\text { Online Brand Community } \\
\text { Impression Management }\end{array}$ & .22 & *2.57 \\
\hline & $\begin{array}{l}\text { Online Brand Community } \\
\text { Community Engagement }\end{array}$ & .84 & $* * 8.01$ \\
\hline & $\begin{array}{l}\text { Online Brand Community } \\
\text { Brand Use }\end{array}$ & .64 & $* * 7.75$ \\
\hline \multirow[t]{3}{*}{$\mathrm{H} 3$} & $\begin{array}{l}\text { Online Brand Community } \\
\text { Community Loyalty }\end{array}$ & .71 & $* * 7.92$ \\
\hline & $\begin{array}{l}\text { Community Identification } \\
\text { Community Loyalty }\end{array}$ & .86 & $* * 10.71$ \\
\hline & $\begin{array}{l}\text { Organizational Citizenship Behavior } \\
\text { Community Loyalty }\end{array}$ & .75 & $* * 9.90$ \\
\hline
\end{tabular}

Table 3.Results of Testing. Notes $(* * p<.001)$

\section{The Mediating Effects of Community Loyalty}

Since community loyalty is operationalized as a second-order reflective latent construct with the two first-order reflective indicators, community identification and organizational citizenship behavior, the significance of indicators was tested. The results showed that both community identification $(\beta=.86)$ and organizational citizenship behavior $(\beta=.75)$ are significant reflective indicators of community loyalty at $\mathrm{p}<.001$ level.

Hypothesis 3 was supported (Table 3 ). The effects of online brand community on community loyalty were significant $(\beta=.71)$ at $p<.001$ level.

Hypothesis 4 was supported (Fig 2).The mediating effects of community loyalty were revealed. As supported in hypotheses 2, the online brand community has positive effects on four value creation practices. However, when community loyalty is included as a mediator between the two constructs, the effects of online brand community on all value creation practices were dropped in magnitude. With community loyalty as a mediator in the model, the effects of online brand community on social networking $(\beta=-.03)$, impression management $(\beta=-.07)$, community engagement $(\beta=-.14)$, and brand use $(\beta=.04)$ were all became non-significant $(p>1)$. The effects of community loyalty on four value creation practices, social networking $(\beta=.91)$, impression management $(\beta=.27)$, community engagement $(\beta=.92)$, and brand use $(\beta=.58)$ practices, were all significant at the levels of $p<.001$, except for the impression management construct $(\mathrm{p}<.01)$. 


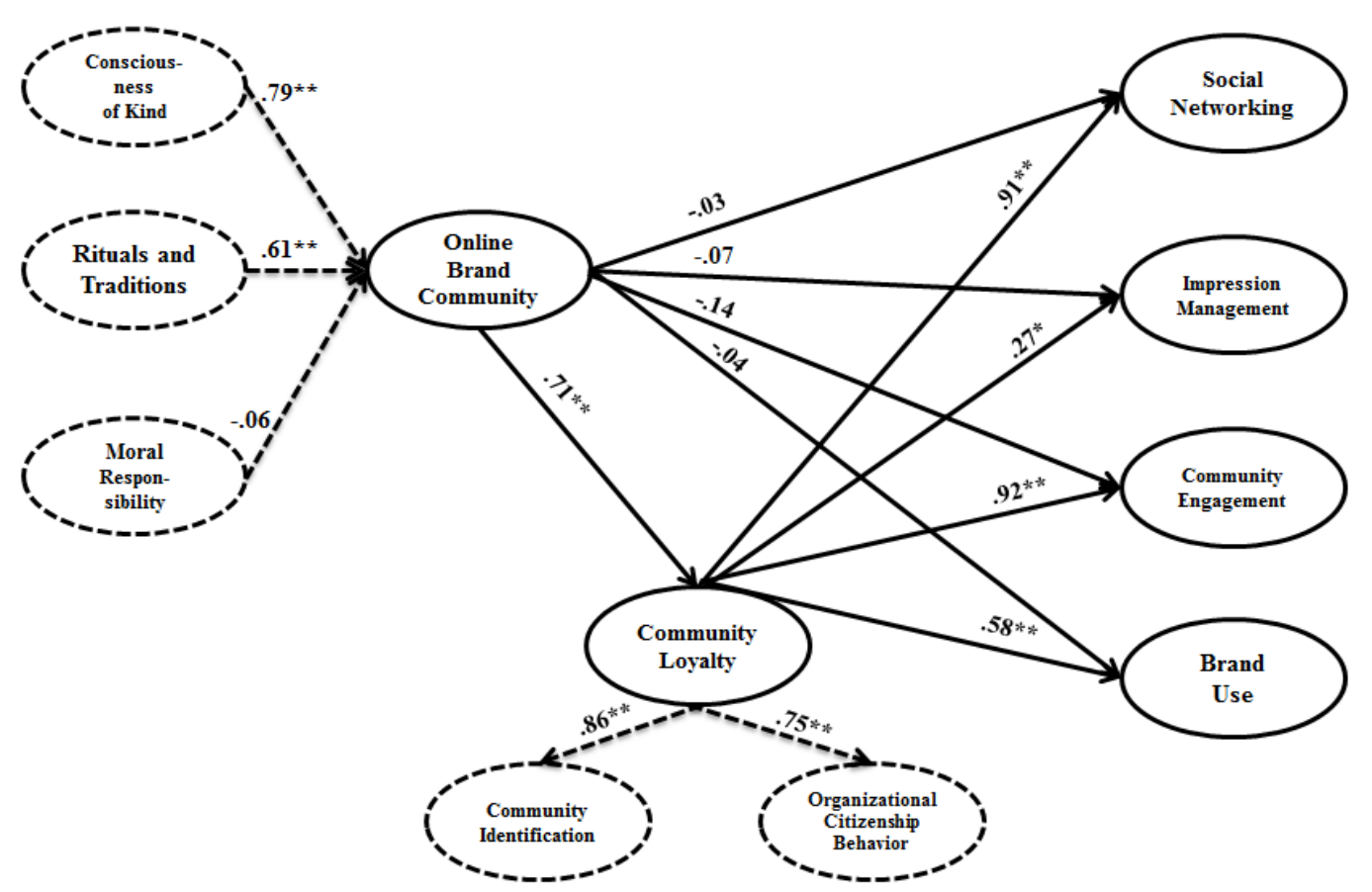

Figure 2.Mediating Effects of Community Loyalty. Notes $\left({ }^{* *} p<.001,{ }^{*} p<.01\right)$

\section{Discussion and Implications}

The test of hypothesis one reveals that online brand community is a latent construct that is formed by the influences of consciousness of kind and rituals and traditions. The present study modeled the direction of causality flows from community markers to online brand community. The results imply that as members feel and recognize consciousness of kind with other members, and rituals and traditions of online brand community strengthen, the levels of online brand community increase.

Such findings make sense in that consciousness of kind and rituals and traditions are related with each other regarding their practices. Showing legitimacy is one way of perpetuating consciousness of kind among online brand community members, and members show their legitimacy by appreciating rituals and traditions of the community. For example, when a member shares brand stories or consumption experiences with other members as a way of conforming to rituals and traditions of the online brand community, such activities simultaneously reveal that the member respects the rules and expected roles of the online brand community. As a consequence, those activities, conforming to rituals and traditions of the online brand community, eventually reinforce the consciousness of kind among members of the community.

Therefore, marketers should promote rituals and traditions of the online brand community which can make members feel and recognize consciousness of kind with other members. Marketers can assist in the cause of rituals and traditions by publishing socialization materials within online brand community such as brand history, consumption story, myths, and insider talk in the form of marketing communications (Muniz \& O'Guinn, 2001). Considering that online brand community members tend to passively engage in sustaining rituals and traditions and weakly develop consciousness of kind, compare to traditional, offline brand community, promoting rituals and traditions to strengthen consciousness of kind among community members would be more important in online brand communities.

Moral responsibility showed non-significant effects on online brand community. Although online brand community is a voluntary group, there exists moral consciousness among members both to the community and individual members. However, this study reveals that moral responsibility is not a significant formative indicator of online brand community.

Even though online brand community members show a sense of duty to the community and to other members, as it is shown in cooperation or helping, such activities are proved to be a behavioral form of community loyalty rather than activities based on a moral responsibility. The non-significant effects of 
moral responsibility imply that moral responsibility is not an organic element of online brand community which could be spontaneously derived from like-minded members. This finding illustrates Wirtz et al.'s (2013) point that online brand community members carry less moral responsibility since online brand community allows members to reveal only little of their identity. Our study shows that members' sense of duty to online brand community could be generated in a form of community loyalty only when the levels of online brand community strengthen as a linear sum of consciousness of kind and rituals and traditions. The moral responsibility of members could not be created by soliciting members to be responsible to the community or enforcing them using the threat of sanctions. Thus, enhancing members' community loyalty would be critical to make members responsible to the community.

The test of hypothesis two shows that online brand community significantly effects on all four value creation practices, social networking, brand use, community engagement, and impression management. Among the four value creation practices, the online brand community showed the strongest effect on social networking practice $(\beta=.95)$, moderate effects on community engagement $(\beta=.84)$ and brand use $(\beta=.64)$ practices, and the weakest effect on impression management $(\beta=.22)$ practice.

The test results of hypothesis two align with the finding that consciousness of kind and rituals and traditions are significant indicators of online brand community, while moral responsibility is not. Since social networking practice emphasizes on the homogeneity and similarity across community members, it is believed to be based on consciousness of kind among the members of the online brand community. Our study showed that as the levels of online brand community increase, members with a heightened consciousness of kind actively engage in social networking practices such as welcoming, empathizing, and governing.

The online brand community showed moderate effects on community engagement and brand use practices. Community engagement and brand use practices are related to rituals and traditions of online brand community. Although community engagement practices relate to ineffectual domain (e.g. stacking, mile stoning, badging, and documenting) and brand use practices relate to a functional domain (e.g. commoditizing, grooming, and customizing), both practices are about sharing consumption experiences of a focal brand with other members. Considering that one of the most prevalent rituals and traditions shown in the online brand community is sharing consumption experiences (Muniz \& O'Guinn, 2001), it makes sense that strong online brand community which has perpetuating rituals and traditions generates vibrant brand use and community engagement practices.

Additionally, the significant effects of online brand community on social networking practice and brand use practice could be an evidence showing that online brand community produces altruistic behaviors and collective actions, even without the presence of moral responsibility. For example, social networking practice leads members to behave altruistically by articulating behavioral expectations for community members. Through brand use practice, members spontaneously accumulate expertise on individual topics within online brand community, and it helps other members who seek for reliable information regarding the consumption of a focal brand.

Impression management practice was shown as a significant, albeit, relatively weak outcome of online brand community. Impression management practice requires more personal sacrifice of members compare to other value creation practices because of its external and outward focus. Since impression management practice frequently goes beyond members' role prescriptions, it requires moral responsibility and/or altruistic motivation of members for it being conducted. As moral responsibility showed nonsignificant effects on online brand community, it makes sense that online brand community has the weakest impact on impression management practice. Moreover, the outcomes of impression management practice are not tangible as other practices. The outcomes of inspiring or rationalizing others could not be explicitly revealed as posting a greeting message or providing an informational advice to other members. Considering that achieving social status within the community by demonstrating their performances is one important driver that makes members engaging in practices, such intangible aspects may hinder members from engaging in impression management practices.

The test of hypothesis three demonstrates that even though moral responsibility is not an endemic element of online brand community, community loyalty is heightened as the levels of online brand community increase. Our study measured community loyalty as it consists of cognitive, affective, and 
behavioral aspects, using community identification and organizational citizenship behavior constructs. Since online brand community members share consciousness of kind, and rituals and traditions of the community systemically reinforce consciousness of kind among members, members perceive similarity to and liking for other members as the levels of online brand community increase. Members also identify themselves to the community and make salient a norm of social responsibility for in-group members. As a consequence, members' loyalty toward the community is heightened as online brand community strengthens.

Hypothesis four was tested to investigate the role of community loyalty in online brand community. As we examined the role of community loyalty, we found that community loyalty fully mediates the relationship between online brand community and value creation practices. The results imply that making members loyal to the community is crucial to ensure their engagement in value creation practices.

The test of hypothesis four revealed that online brand community members do not spontaneously engage in value creation practices unless they are loyal to the community. The mediating effects of community loyalty could be due to the evolving nature of practices. Practices have a trajectory of development and act as apprenticeship (Lave \& Wenger, 1991; Warde, 2005). It evolves over time as community members engage in practices deeply and practices are integrated. Because values from participating in practices are not created immediately, it requires members' personal sacrifice or investment in terms of their time and effort for its value to be created. For example, welcoming is usually the first practice to which members are exposed. When new members engage in welcoming practice, they frequently reveal their consumption experiences or personal expertise as a way of introducing themselves. In such case, new members are naturally adopted and recruited to documenting and customizing practices which are considered as more complex practices. While engaging in various and more complex practices, novice members learn which activities they are expected to engage in and how they are supposed to feel from participating in practices. As Østerlund and Carlile (2005) argued, "they do not merely learn about practices, rather they become practitioners". As practices develop, members' standing and legitimacy within the community increase, they achieve social status and meet their desired social identity, and values from engaging in practices expand. Because practices act as apprenticeship and their outcomes are not immediate and intuitive, members should bear the times and efforts until their participations create actual values for them. However, since moral responsibility to the community is not an endemic element of online brand community, it is hard for members to bear those sacrifices unless they have community loyalty.

Since community loyalty leads community members to acts of altruism, cooperation and helpfulness without any current rewards or reputational acknowledgement (Dawes et al., 1990; Katz, 1964), marketers can ensure members' consistent engagement in value creation practices, even during the period of apprenticeship, by enhancing their community loyalty. This study suggests several ways for marketers to enhance online brand community members' community loyalty. For online brand community members, rewards from joining the community should not be tied to financial incentives. As Barnes (2001) argued, "it is all about how you make them feel". A sense of community is a significant predictor of loyalty to the sponsoring organization (Rosenbaum et al., 2005). It refers to "a feeling of belonging, a belief that members matters to one another and to the overall group, and a shared faith that members' needs will be met through their commitment to be together" (McMillian \& Chavis, 1986). Online brand community can generate a sense of community among members by providing them with affective benefits such as influence and status (McMillian \& Chavis, 1986), and functioning as a consumer agency. All of each benefit increase members' community loyalty by enhancing their community identification and leading them to organizational citizenship behaviors.

First, online brand community can enhance members' community loyalty by providing members with influence. Influence is members' feeling empowered to influence the community (McMillian \& Chavis, 1986). Online brand community members achieve a sense of influence when they believe that they could possess influence over the focal brand through participating in the community. For example, online brand community members may achieve a sense of influence when a focal brand collects innovative ideas from the community. Because they believe that their thoughts and suggestions could be reflected in a focal 
brand by participating in online brand community, they achieve a sense of mattering, and such empowered feeling leads members to form a sense of community.In particular, utilizing brand use practices, marketers could generate an environmentthat allows members to express their opinions and thoughts related to consumption experiences. Generating bulletin boards or discussion forums particularly designed to share ideas for product improvement would induce members to suggest their opinions more easily. Using virtual interaction and communication tools, marketers also should provide online brand community members with timely feedback so that they can realize how their suggestions actually influence the focal brand. Through engaging in such processes, online brand community members would become relying more on the community to influence the focal brand as a group, and subsequently show a heightened community loyalty. At the same time, marketers can achieve grassroots $R \& D$ for the improvement of products or services from the devoted users of their brands.

Second, online brand community can enhance members' community loyalty by providing members with status. Once new members gain some experiences within online brand community, they inevitably recognize their lowly status (Schouten \& McAlexander, 1995). Achieving a desired social identity is an important driver that makes consumers joining in online brand community. Members form community loyalty as they achieve status both within and across the community. Online brand community can compensate for members' commitment to the community by providing them with status. For example, displaying an accumulated number of postings or participations aside members' name would publicly show their contributions to the community and discern them as experienced members. Members' community loyalty also increases when their online brand community has higher status within across-group hierarchy. Across-group hierarchy is judged by consumers based on the authenticity of the community (Schouten \& McAlexander, 1995). Thus, marketers can confer an authentic status to a particular online brand community by acknowledging the authenticity conferred by the brand. Providing promotional items that display authenticity, such as iconic-emblem, could create a sense of affiliation to the authentic community for online brand community members. It will make members to feel that their community has a higher status compare to other online brand community and enhance members' community loyalty.

Third, online brand community can enhance members' community loyalty by functioning as a consumer agency. A sense of community is also formed when community members believe that the community has some influences over them. Online brand community members frequently gauge a success of brand different from marketers. For the brands that have enthusiastic supporting consumer groups, lines of marginality between the true members and the opportunistic become blurred and the distinctiveness of the brand is lost when it reaches to mainstream consumers (Schouten \& McAlexander, 1995). The preservation of brand's meaning is important to brand community members. Online brand community can act as a consumer agency so that members can carry through their convictions to the brand. For example, online brand community can keep reproducing the original meanings of the brand, regardless of its commercial reasons, by fostering rituals and traditions that emphasize on the authenticity of the brand. Although such activities may seem as opposing to a market-driven strategy, it would convince members of fulfillments of their needs through the community, and increase members' community loyalty.

By enhancing community loyalty, all of the above-mentioned benefits (e.g., providing members with influence and status, functioning as a consumer agency) would compensate for members' sacrifices, and help online brand community members to bear the periods of apprenticeships until practices create actual values for them.

\section{Limitations and Future Research}

Despite its contributions, there are some limitations in this research.

First, moderators of the online brand community are not considered in the model. Members' reaction to the online brand community could be different according to moderators such as participating times, membership durations, and/or motivation for participation (Wirtz et al., 2013).Among various moderators that may affect the online brand community, investigating the role of motivation for participation would be a fruitful area for future research. Considering that some consumers participate in brand community to seek for direct satisfaction through sharing emotions or developing relationships 
with other members while others participate with more practical reasons (Cova, 1997; McAlexander, 2002), a group comparison between hedonic and instrumentalmotivation groups could reveal a meaningful findingregarding members' reactions to online brand community.

Second, regarding the purpose of this study, we mainly focused on the relationships between online brand community, community loyalty, and value creation practices. However, future research may consider the outcomes of value creation practices, such as brand loyalty, as the end variable of the online brand community. One of the primary goals of brand community is gaining loyal customers (McAlexander et al., 2002), and online brand community engagements often translate into brand loyalty (Wirtz et al., 2013).Thus, testing the effects of value creation practices on brand loyalty, with the mediating effects of community loyalty between the two constructs, would provide more insights into brand community research.

\section{Reference}

Adler, P. A., \& Adler, P. (1988).Intense loyalty in organizations: A case study of college athletics. Administrative Science Quarterly, 33(3), 401-417.

Ahearne, M., Bhattacharya, C.B., \&Grues, T. (2005). Antecedents and consequences of customer-company identification: expanding the role of relationship marketing. Journalof Applied Psychology, 90(3), 57485.

Algesheimer, R., Dholakia, U.M., \& Herrmann, A. (2005). The social influence of brand community: Evidence from European car clubs. Journal of Marketing, 69(3), 19-34.

Anderson, P. H. (2005). Relationship marketing and brand involvement of professionals through webenhanced brand communities: The case of Coloplast. Industrial Marketing Management, 34(3), 285297.

Anderson, B. (1983). Imagined community, London: Verso.

Anderson, J. C., \& Gerbing, D. W. (1988). Structural equation modeling in practice: A review and recommended two-step approach.Psychological Bulletin, 103(3), 411-423.

Arnould, E.J., \& Price, L. (2000). Authenticating acts and authoritative performances: Questioning for self and community. InR, Srinivasan.,G, M. David., \& H, Cynthia. (Eds), The Why of Consumption: Contemporary perspectives on consumer motives, goals, and desires. Routledge, New York, NY, pp. 14063.

Arrow, H., McGrath, J. E., \& Berdahl, J. L. (2000). Small groups as complex systems. London: Sage.

Aubert-Gamet, V. \& Cova, B. (1999).Servicescapes: From modern non-places to postmodern commonplaces. Journal of Business Research, 44(1), 37-45.

Ba, S. (2001).Establishing online trust through a community responsibility system.Decision Support System, 31, 323-336.

Babin, B. J., Darden, W. R., \& Griffen, M. (1994).Work and/or fun: measuring hedonic and utilitarian shopping value.Journal of Consumer Research, 20(4), 644-656.

Bagozzi, R. P. (1981). Evaluating structural equation models with unobservable variables and measurement error: A Comment. Journal of Marketing Research, 18, 375-381.

Bagozzi, R. P., \& Dholakia, U. M. (2002).Intentional social action in virtual communities.Journal of Interactive Marketing, 16 (2), 2-21.

Bagozzi, R. P., \& Dholakia, U. M. (2006). Open source software user communities: A study of participation in Linux user groups. Management Science, 52(7), 1099-1115.

Bagozzi, R., \& Yi, Y. (1988). On evaluation of structural equation models. Journal of the Academy of Marketing Science, 16, 74-94.

Barnes, J. G. (2001).Secrets of customer relationship management: It's all about how you make them feel. New York, NY: McGraw-Hill.

Barreto, M., \& Ellemers, N. (2000). You can't always do what you want: Social identity and selfpresentational determinants of the choice to work for a low-status group. Personality and Social Psychology Bulletin, 26, 891-906.

Batson, C. D., Batson, J. G., Todd, R. M., Brummett, B. H., Shaw, L. L., \& Aldeguer, C. M. R. (1995). Empathy and the collective good: Caring for one of the others in a social dilemma. Journal of Personality and Social Psychology, 68, 619-631. 
Blalock, H. M. (1964).Causal Inferences in no experimental research. New York, NY: Norton.

Bollen, K. (1989). A new incremental fit index for general structural equation models. Sociological Methods $\mathcal{E}$ Research, 17(3), 303-316.

Bollen, K., \& Lennox, R. (1991). Conventional wisdom on measurement: A structural equation perspective. Psychological Bulletin, 110(2), 305-314.

Bourdieu, P. (1984). Distinction: A social critique of the judgment of taste. Cambridge, MA: Harvard University Press.

Brabham, D. C. (2010).Moving the crowd at Threadless. Information, Communication, \& Society, 13(8), 11221145.

Brewer, M. B., \& Brown, R. J. (1998).Intergroup relations. In D. T. Gilbert, S. T. Fiske, \& G. Lindzey (Eds.), the handbook of social psychology (pp. 554-594). Boston, MA:McGraw-Hill.

Brodie, R. J., Ilic, A., Juric, B., \& Hollebeek, L. (2013). Consumer engagement in a virtual brand community: An explanatory analysis. Journal of Business Research, 66, 105-114.

Bryman, A., \& Bell, E. (2007). Business research methods. New York, NY: Oxford University Press.

Buhrmester, M., Kwang, T., \& Gosling, S. D. (2011). Amazon's mechanical Turk: A new source of inexpensive, yet high-quality, data? Perspective on Psychological Science, 6(1), 3-5.

Carroll, B. A., \&Ahuvia, A. C. (2006). Some antecedents and outcomes of brand love. Marketing Letters, 17, 79-89.

Cova, B. (1997). Community and consumption: Towards a definition of the "linking value" of product or services. European Journal of Marketing, 31(3/4), 297-316.

Cronbach, L. J., \&Furby, L. (1970). How we should measure "change" - or should we? Psychological Bulletin, 74(1), 68-80.

Dawes, R. M., Van de Kragt, A. J. C., \& Orbell, J. M. (1990).Cooperation for the benefit of us - Not me, or my conscience. In J. J. Mansbridge (Ed.), Beyondself-interest (pp. 97-100). Chicago, IL: Univ. of Chicago Press.

De Valck, K., Van Bruggen, G., \&Wierenga B. (2009). Virtual communities: A marketing perspective. Decision Support Systems, 47, 185-203.

Deshpandé, R. (1983). Paradigms lost: On theory and method in research in marketing. Journal of Marketing, 47, 101-110.

Dovidio, J. F. (1984). Helping behavior and altruism: An empirical and conceptual overview.Advances in Experimental Social Psychology, 17, 361-427.

Edlund, J. E., Sagarin, B. J., Skowronski, J. J., Johnson, S. J., \&Kutter, J. (2009). Whatever happens in the laboratory stays in the laboratory: The prevalence and prevention of participant crosstalk. Personality and Social Psychology Bulletin, 35, 635-642

Edwards, J. R. (2003). Construct validation in organizational behavior research. In J.Greenberg (Ed.), Organizational Behavior: The State of the Science(pp. 327-371). Mahwah, NJ: Lawrence Erlbaum Associates.

Ellemers, N., Spears, R., \&Doosje, B. (2002).Self and social identity.Annual Review of Psychology, 53, 161186.

Elliott, R., \&Wattanasuwan, K. (1998).Brands as symbolic resources for the construction of identity. International Journal of Advertising, 17, 131-144.

Etgar, M. (2008).A descriptive model of the consumer co-production process. Journal of the Academy of Marketing Science, 36(1), 97-108.

Fornell, C., \&Bookstein, F. L. (1982), Two structural equation models: LISREL and PLS applied to consumer exit-voice theory. Journal of Marketing Research, 19, 440-452.

Fornell, C., \& Cha, J. (1994). Partial least squares. In: B, Richard (Ed.), Advanced Methods of Marketing Research (pp. 52-78). Cambridge, MA, Basil Blackwell.

Fornell, C., \& Larker, D. F. (1981).Evaluating structural equation models with unobserved variables and measurement error. Journal of Marketing Research, 39-50.

Fournier, S. (1998). Consumers and their brands: Developing relationship theory in consumer research. Journal of Consumer Research, 24(4), 343-353.

Fournier, S., \& Lee, L. (2009). Getting brand communities right. Harvard Business Review, 87(4), 1-10. 
Franke, N., \&Piller, F. (2004).Value creation by toolkits for user innovation and design.Journal of Product Innovation Management, 21, 401-415.

Gosling, S., Vazire, S., Srivastava, S., \& John, O. (2004). Should we trust web-based studies? A comparative analysis of six preconceptions about internet questionnaires.American Psychologist, 59, 93-104.

Gusfield, J. (1978). Community: A critical response. New York, NY: Harper and Row

Hertel, G., \& Kerr, N. L. (2001).Priming ingroup favoritism: The impact of normative scripts in the minimal group paradigm. Journal of Experimental Social Psychology, 37, 316-324.

Hinkle, S., Taylor, L. A., Fox-Cardamone, L., \& Crook, K. F. (1989). Intragroup identification and intergroup identification: A multicomponent approach. British Journal of Social Psychology, 28, 305317.

Hoffman, D. L., \& Novak, T. P. (1996). Marketing in hypermedia computer-mediated environments: Conceptual foundations. Journal of Marketing, 60, 50-68.

Holt, D. B. (1995). How consumers consume: A typology of consumption. Journal of Consumer Research, 22, $1-16$.

Hulland, J. (1999). Use of partial least squares (PLS) in strategic management research: A review of four recent studies. Strategic Management Journal, 20, 195-204.

Hur, W., Ahn, K., \& Kim, M. (2011).Building brand loyalty through managing brand community commitment. Management Decision, 49(7), 1194-1213.

James, K., \&Cropanzano, R. (1994). Dispositional group loyalty and individual action for the benefit of an in-group: Experimental and correlational evidence. Organizational Behavior and Human Decision Processes, 60, 179-205.

Jannowitz, M. (1952). The Community Press in an Urban Setting, Glencoe, IL: Free Press.

Jarvis, C. B., Mackenzie, S. B., \&Podsakoff, P. M. (2003).A critical review of construct indicators and measurement model misspecification in marketing and consumer research.Journal of Consumer Research, 30(2), 199-218.

Johnson, M. D., Morgeson, F. P., Ilgen, D. R., Meyer, C. J., \& Lloyd, J. W. (2006). Multiple professional identities: Examining differences in identification across work-related targets. Journal of Applied Psychology, 91(2), 498-506.

Kang, I., Lee, K. C., Lee, S., \& Choi, J. (2007).Investigation of online community voluntary behaviour using cognitive map.Computers in Human Behavior, 23, 111-126.

Katz, D. (1964). The motivational basis of organizational behavior. Behavioral Science, 9, 131-133.

Kozinets, R. V. (2002). The field behind the screen: Using netnography for marketing research in online communities. Journal of Marketing Research, 39, 61-72.

Krantz, J. H., \&Dalal, R. (2000).Validity of web-based psychological research. In M. H. Birnbaum (Ed.), Psychological experiments on the Internet (pp. 35-60). New York, NY: Academic Press.

Krebs, D. L. (1970).Altruism; an examination of the concept and a review of the literature Psychological Bulletin, 73, 258-302.

Laroche, M., Habibi, M. R., Richard, M. O., \&Sankaranarayann, R. (2012). The effects of social media based brand communities on brand community markers, value creation practices, brand trust and brand loyalty. Computers in Human Behavior, 28, 1755-1767.

Lave, J., \& Wenger, E. (1991). Situated learning: Legitimate peripheral participation. Cambridge, UK: Cambridge University Press.

Law, K., \& Wong, C. (1999). Multidimensional constructs in structural equation analysis: An illustration using the job perception and job satisfaction constructs. Journal of Management, 25 (2), 143-160.

Levine, J. M., \& Moreland, R. L. (2002).Group reactions to loyalty and disloyalty. In E. Lawler \& S. Thye (Eds.), Group cohesion, trust, and solidarity: Advances in group processes (Vol. 19, pp. 203-228). Amsterdam: Elsevier Science.

Mackenzie, S. B., Podsakoff, P. M., \&Podsakoff, N. P. (2011).MIS quarterly, 35(3), 293-334.

Maclnnis, D. J., Moorman, C. M., \&Jaworski, B. J. (1991). Enhancing and measuring consumers' motivation, opportunity and ability to process brand information from ads. Journal of Marketing, 53(10), 10-23.

Manchanda, P., Packard, G., \&Pattabhiramaiah, A. (2012). Social dollars: the economic impact of customer 
participation in a firm-sponsored online community. MSI Report, 11, 115.

Marzocchi, G., Morandin, G., \&Bergami, M. (2013).Brand communities: Loyal to the community or the brand?.European Journal of Marketing, 47, 93-114.

Mathwick, C., Wiertz, C., \&Ruyter, K. (2008).Social capital production in a virtual p3 community. Journal of Consumer Research, 34(6), 832-849.

McAlexander, J.H., \& Schouten, J.W. (1998).Brandfests: Servicescapes for the cultivation of brand equity. Sherry, J.F. Jr (Ed.), Serviscapes: The Concept of place in contemporary markets (pp. 377-402). Chicago, IL: American Marketing Association.

McAlexander, J. H., Schouten, J. W., \& Koenig, H. F. (2002).Building brand community. Journal of Marketing, 66, 38-54.

McMillian, D.W., \&Chavis, D.M. (1986). Sense of community: A definition and theory. Journal of Community Psychology, 14(1), 6-23.

Muniz, A.M. Jr., \&O'Guinn, T. C. (2001).Brand community. Journal of Consumer Research, 27(4), 412-432.

Nambisan, S., \& Baron, R. A. (2007). Interactions in virtual customer environments: Implications for product support and customer relationship management. Journal of Interactive Marketing, 21(2), 4262.

Nunnally, J. (1967).Psychometric methods. New York, NY: McGraw-Hill.

Oliver, R.L. (1999). Whence consumer loyalty? Journal of Marketing, 63, 33-44.

Organ, D.W. (1988).Organizational citizenship behavior: The good soldier syndrome. Lexington, MA: Lexington Books.

Orne, M. T. (1962). On the social psychology of the psychological experiment: With particular reference to demand characteristics and their implications. American Psychologist, 17, 776-783

Østerlund, C., \&Carlile, P. (2005). Relations in practice: Sorting through practice theories on knowledge sharing in complex organizations. The Information Society, 21, 91-107.

Paolacci, G., Chandler, J., \&Ipeirotis, P. G. (2010). Running experiments on Amazon Mechanical Turk. Judgement and Decision Making, 5(5), 411-419.

Podsakoff, P. M., Mackenzie, S. B., Moorman, R. H., \& Fetter, R. (1990). Transformational leader behaviors and their effects on followers' trust in leader, satisfaction, and organizational citizenship behaviors. Leadership Quartely, 1(2), 107-142.

Prügl, R., \& Schreier, M. (2006). Learning from leading-edge customers at the Sims: Opening up the innovation process using toolkits. RED Management, 36(3), 237-250.

Robertson, D. C., \& Breen, B. (2013). Brick by brick: How LEGO rewrote the rules of innovation and conquered the global toy industry. New York, NY: Crown Business.

Rosenbaum, M. S., Ostrom, A. L., \&Kuntze, R. (2005).Loyalty programs and a sense of community.Journal of Services Marketing, 19(4), 222-233.

Schau, H. J., Muniz, A. M., Jr., \&Arnould, E. J. (2009). How brand community practices create value. Journal of Marketing, 73, 30-51.

Schouten, J. W., \&McAlexander, J. H. (1995). Subcultures of consumption: An ethnography of the new bikers. Journal of Consumer Research, 22, 43-61.

Scott, W. (1965).Values and organizations: A study of fraternities and sororities. Chicago, IL:Rand McNally.

Seashore, S E. (1954).Group cohesiveness in the industrial work group. Ann Arbor, MI: University of Michigan Press.

Shen, C. C., \&Chiou, J. S. (2009). The effect of community identification on attitude and intention toward a blogging community. Internet Research, 19(4).393-407.

Smith, C. A., Organ, D. W., \& Near, J. P. (1983). Organizational citizenship behavior: Its nature and antecedents. Journal of Applied Psychology, 68(4), 653-663.

Stern, P. C. (1995). Why do people sacrifice for their nations? Political Psychology, 16, 217-235.

Szmigin, I., \&Reppel, A. E. (2001). Internet community bonding: The case of macnews.de. European Journal of Marketing, 38, 626-640.

Tajfel, H., \& Turner, J. C. (1986).The social identity theory of intergroup behavior. In S. Worchel\& W. Austin (Eds.), Psychology of intergroup relations (pp. 7-24). Chicago, IL:Nelson-Hall.

Thompson, J. D.(1967). Organizations in action. New York, NY: McGraw-Hill. 
Thompson, S. A., \& Sinha, R. K. (2008). Brand communities and new product adoption: The influence and limits of oppositional loyalty. Journal of Marketing, 72(6), 65-80.

Turner, J. C., Hogg, M. A., Oakes, P. J., Reicher, S. D., \&Wetherell, M. (1987).Rediscovering the social group: A self-categorization theory. Oxford, England: Basil Blackwell.

Van Vugt, M., \& Hart, C. M. (2004). Social identity as social glue: The origins of group loyalty. Journal of Personality and Social Psychology, 86(4), 585-598.

Von Hippel, E. A. (2005). Democratizing innovation. Cambridge, MA: MIT Press.

Warde, A. (2005). Consumption and theories of practice. Journal of Consumer Culture, 5(2), 131-153.

Weber, M. (1978).Economy and society. Berkeley, CA: University of California Press.

White, J.C., Varadarajan, P.R., \&Dacin, P.A. (2003). Market situation interpretation and response: The role of cognitive style, organizational culture, and information use. Journal of Marketing, 67(3), 63-79.

Wiertz, C., \& de Ruyter, K. (2007). Beyond the call of duty: Why consumers contribute to firm-hosted commercial online communities. Organization Studies.28 (3), 347-76.

Wilder, D. A. (1986). Social categorization: Implications for creation and reduction of intergroup bias. In L. Berkowitz (Ed.), Advances in experimental social psychology (Vol. 19, pp. 291-355). New York, NY: Academic Press.

Wirtz, J., Ambtman, A., Bloemer, J., Horvath, C., Ramaseshan, B., Klundert, J, Canli, Z. G., \&Kandampully, J. (2013).Managing brands and customer engagement in online brand communities.Journal of Service Management, 24(3), 223-344.

Wolin, J. S., \& Bennett, L. (1984).Family rituals. Family Process, 23(3), 401-420.

Zdaniuk, B., \& Levine, J. M. (2001). Group loyalty: Impact of members' identification and contributions. Journal of Experimental Social Psychology, 37, 502-509. 